\title{
Risico's voor accountants als aanbieders van assurance services
}

\author{
Prof. Dr. E.H.J. Vaassen en Drs. C.C.M. Schelleman
}

\section{Inleiding}

Een gerenommeerd medisch onderzoeksinstituut kwam enige tijd geleden op negatieve wijze in het nieuws omdat de verdenking was gerezen dat het bij proeven gebruik had gemaakt van menselijke embryo's. Het instituut ontkende dit in alle toonaarden, maar het kwaad was al geschied. Het 'maatschappelijk verkeer' geloofde dit niet zonder meer en wilde zekerheid over het waarheidsgehalte van deze uitspraak. Op grond van zijn deskundigheid op het terrein van het controleren van informatie - de controle van financiële verantwoordingen zoals de jaarrekening - werd een accountant gevraagd zijn oordeel te geven over de vraag of al dan niet gebruik was gemaakt van menselijke embryo's. Begaf deze accountant zich op glad jjs of was deze dienst een logisch uitvloeisel van zijn deskundigheid? Met dit extreme voorbeeld van een assurance service is de kern van de probleemstelling van dit artikel geraakt, namelijk: wat zijn de risico's als accountants dit soort nieuwe producten gaan aanbieden ${ }^{1 \text { ? }}$

Accountants zijn het erover cens dat de markt voor hun traditionele product, de controle van financiële verantwoordingen, is verzadigd (zie onder andere Elliott, 1994 p. 107 , 1995 p. 118,1997 p. 61 en 1998 p. 1; AlCPA,

Prof. Dr. E.H.J. Vaassen RA is hoogleraar BIV/AO aan de Universiteit van Amsterdam en vaktechnisch adviseur bij Deloitte \& Touche

Drs. C.C.M. Schelleman is als AlO verbonden aan het Maastricht Accounting and Auditing Research and Education Center van dezelfde universiteit.
1997; King en Schwartz, 1998 p. 9; en een recente discussie in de Accountant tussen Waardenburg, Wallage en Van den Hoek, 1999 p. 84). De vraag naar accountantscontrole is weliswaar stabiel, maar door de toegenomen concurrentie is er een neerwaartse druk op de prijs ontstaan. Daarenboven heeft de opkomst van de informatie- en communicatietechnologie (ICT) ertoe geleid dat de aan accountantscontrole te besteden uren drastisch zijn verminderd. Voor accountantskantoren zijn deze ontwikkelingen aanleiding geweest om op zoek te gaan naar nieuwe marktmogelijkheden. Als gevolg hiervan kon een golf van innovaties worden waargenomen in de wereld van de accountancy. Nieuwe producten en instrumenten werden geïntroduceerd zoals: forensische accountancy, milieu-accountancy, operational auditing, clektronische dossiervorming, en het gebruik van ICT om controleprogramma's samen te stellen en de controle te ondersteunen. De meest in het oog springende innovatie is momenteel echter de uit Noord-Amerika overgewaaide opkomst van de assurance services, anders dan de jaarrekeningcontrole de overige assurance services of kortweg assurance services. Inaugurele redes worden hieraan gewijd ${ }^{2}$ en speciale onderzoekscomités worden in het leven geroepen ${ }^{3}$. Op accountancycongressen worden spreekbeurten gehouden waarin verschillende deskundigen onafhankelijk van elkaar tot de conclusie komen dat er een enorm terrein braak ligt waarop de accountant zich kan begeven ${ }^{4}$. Er is echter ook kritiek te beluisteren. Zelfbenoemde aanklagers (zich soms aanduidend met de term 'accountantswatchers'), maar ook serieuzere critici constateren een aantal risico's voor de accountant die 
zich begeeft op het terrein van de assurance services. Ongeacht de status van deze aanklagers moeten de onderkende risico's nader worden onderzocht omdat een vertrouwensbreuk tussen accountants en het maatschappelijk verkeer de ondergang van het beroep zal inluiden. Deze wetenschappelijke uitdaging is inmiddels onderkend en opgepakt door onderzoekers uit de hele wereld. Tot op heden heeft dit echter nog niet geleid tot een lange lijst van publicaties walarin verslag wordt gedaan van assurance services-onderzock. Wél is reeds een aantal artikelen gepubliceerd of gepresenteerd op symposia waarin mogelijkheden voor onderzoek op het terrein van assurance services worden aangegeven (zie onder andere Careello c.a., 1998: Gray en Debreceny. 1998: Vaassen c.a.. 1999: Dassen, 1998 en 1999).

Dit artikel maakt een inventarisatic van de beroepsrisico"s dic accountants als aanbieders van assurance services lopen. Het zal blijken dat deze risico's zijn te herleiden tot twee hoofdcategorieën, namelijk:

risico"s die hun oorsprong vinden in de markt voor accountantswerkzaamheden; vooralsnog is er weinig inzicht in de relatic tussen vraagen aanbodfactoren van assurance services; risico's die hun oorsprong vinden in het proces van accountantswerkzaamheden; rooralsnog is er weinig inzicht in de aard van de processen die ten grondslag liggen aan het uitvoeren van assurance services.

Bij het maken van deze inventarisatic wordt aansluiting gezocht bij wat we al weten over assurance services. Daartoe wordt een bestaande classificatic van onderzoek naar accountantswerkzaamheden uitgebreid. Hoewel het uitgaan van risico's een ietwat negatieve connotatie heeft, is het geenszins de doelstelling van dit artikel om argumenten aan te dragen voor een afwijzing van assurance services als nieuwe vorm van dienstverlening door accountants. Wél wordt getracht aan te geven dat deze risico's tot nader onderzoek moeten leiden om te voorkomen dat de praktijk wordt geconfronteerd met de negatieve effecten van een slecht doordachte introductie.

In de volgende paragraaf wordt allereerst een raamwerk geschetst waarbinnen assurance services en de bijbehorende risico's kunnen worden geclassificeerd. In paragrata 3 wordt vervolgens een overzicht gegeven van bestaand onderzock op het terrein van assurance services. waarna in paragraaf 4 een inventarisatic van risico`s van assurance services wordt gemaakt en in paragraaf 5 enkele concluderende opmerkingen worden gemaakt betreffende de consequenties van dic risico's voor theorie en praktijk.

\section{Een raamwerk voor assurance services}

Het AICPA Special Committee on Assurance Services (1997. kortweg Elliott Committee. naar zijn voorzitter Robert Elliott) definicert assurance services als volgt:

$\because(.$.$) independent professional services that$ improve the quality of information. or its context, for business or individual decision makers.'

Assurance betekent letterlijk 'zekerheid'. Volgens bovenstaande definitie zal de onathankelijke alanbieder van een assurance service (de assurance provider) de kwaliteit van informatie of de context ervan trachten te verbeteren door aan beslissers informatic te verschaffen waaraan zij zekerheid kunnen ontlenen over de gang van zaken binnen een economische entiteit". Dit kan bijvoorbeeld inhouden dat een kwaliteitskeurmerk wordt gegeven bij de activiteiten van dic economische entiteit of de daarover door de entiteit verstrekte informatie (de jaarrekeningcontrole). Het kan echter ook betekenen dat additionele informatie wordt verstrekt die door de economische entiteit zelf niet opgeleverd is $\mathrm{en}$ waarmee een belanghebbende tot een betere besluitvorming zou kunnen komen'. Het begrip "quality of information" wordt derhalve ruim opgevat. Een verdere verruming wordt gevonden in de toevoeging 'or its context'. Deze toevoeging roept echter tevens de vraag op wat wordt bedoeld met de context van informatie. Om enige helderheid te scheppen in het scala van diensten dat onder de noemer assurance services kan worden aangeboden, is het zinvol een raamwerk te hanteren waarin ondubbelzinnig wordt aangegeven wat met de context van informatic wordt bedoeld en over welke kwaliteitsdimensies van informatic zekerheid kan worden gegeven.

Momenteel is een aantal classificaties van assurance services in zwang. De bekendste daarvan is wellicht die zoals gepresenteerd in de 
International Standard on Assurance Engagements van de International federation of Accountants (IFAC, 1998). Hicrin wordt een indeling in de volgende objecten van assurance services gemaakt: (1) historische financiële verantwoordingen; (2) financiële informatic; (3) nict-financiële informatic; (4) systemen en processen; en (5) gedrag. Deze indeling impliceert dat de context van informatie enerzijds wordt gevormd door 'systemen en processen' en anderzijds door 'gedrag'. De objecten van assurance services die deze diensten onderscheiden van de traditionele controle van financiële verantwoordingen zijn volgens deze classificatic te herleiden tot het onderscheid tussen:

historische en toekomstgerichte informatic; de controle van financiële verantwoordingen is primair gericht op historische informatic. waar assurance services ook zijn gericht op tockomstgeoriënteerde informatic;

financiële versus nict-financiële informatie; de controle van financiële verantwoordingen is primair gericht op financiële informatic, waar assurance services ook zijn gericht op nictfinanciële informatic;

systemen versus de uitkomsten van systemen; de controle van financiële verantwoordingen is gericht op de uitkomsten van systemen (namelijk uitkomsten van het financiële informaticsysteem), waar assurance services ook zijn gericht op de systemen zelf; menselijk gedrag versus de resultaten van menselijk gedrag; de controle van financiële verantwoordingen is gericht op de neerslag van menselijk gedrag in een verantwoording. waar assurance services ook zijn gericht op het gedrag zelf.

Er zijn echter meer objecten van assurance services die deze onderscheiden van de traditionele controle van financiële verantwoordingen:

besturing en beheersing van organisaties versus de informatieverzorging daarvoor: de controle van financiële verantwoordingen is gericht op informatic, waar assurance services ook zijn gericht op de besturing en beheersing van organisaties;

betrouwbaarheid van informatic versus relevantic van informatic; de controle van financiële verantwoordingen is primair gericht op de betrouwbarheid van informatic, waar assurance services ook zijn gericht op de relevantie van informatie;

strategisch versus operationeel; de jaarrekeningcontrole is sterk gericht op operationele processen in organisaties, watr assurance services ook strategische aspecten omvatten.

Mede door het feit dat de IFAC-classificatic lijkt te steunen op een aantal willekeurig bij elkaar gezochte criteria en door het ontbreken van een heldere afbakening van de objecten waarop deze diensten zijn gericht. moet deze classificatie nader worden geanalyseerd om beter inzicht te krijgen in de betekenis van het begrip 'de context valn informatic'.

Een classificatic dic uitgaat van de positic in de markt van diensten zoals aangeboden door accountants is die van het Elliott Committee zelt ( $I$ ICPA, 1997). Het Committee deelt assurance services in volgens twee dimensies: (1) traditionele versus nieuwe diensten en (2) traditionele versus nieuwe cliënten. Aangezien we hier op zoek zijn naar een classificatie dic antwoord geeft op de vraag wat de context is van informatic, is deze indeling weinig behulpzalam.

Het onderzocksterrein van assurance services zoals aangeboden door accountants is nog redelijk onontgonnen en een generick ralamwerk wordt ook hier node gemist. Carcello e.a. $(1998, p .4)$ maken een indeling in vijf institutionele gebieden waarvoor reeds onderzocksliteratuur op het terrein van de traditionele accountantscontrole bestaat: (1) markten; (2) beroepsrisico en daaruit mogelijk voortvloeiende procesvoering: (3) communicatic; (4) onathankelijkheid; en (5) meetcriteria. Zij sluiten daarmee niet aan bij een of andere classificatic van assurance services. Het sterke punt van deze classificatie is echter dat ze wél aansluit bij bestaand onderzoek op het terrein van de accountantscontrole.

Dassen (1998, p. 10; 1999, p. 319) vocgt een dimensie toe aan de hierboven besproken IFACclassificatie door een nader onderscheid te maken tussen de vraagzijde van de markt, de aanbodzijde van de markt en de toetsingscriteria en technologie. Binnen het aldus ontstane raamwerk presenteert hij een aantal relevante onderzoeksthema's.

Om cen brug te slaan tussen theorie en praktijk van assurance services en om de tekortkomin- 
gen van de IFAC-classificatie op te vangen, kan een op details aangepast alternatief raamwerk worden geconstrueerd waarbinnen assurance services en de bijbehorende risico's voor accountants kunnen worden ingedeeld. Vaassen e.a. (1999, pp. 9-10) maken de volgende indeling: (1) bedrijfsprocessen (de activiteiten van een economische entiteit waarmee de markt wordt betreden); (2) informatie daarover; en (3) de systemen die worden gebruikt om informatie te verstrekken of die anderszins helpen de bedrijfsvoering te ondersteunen (voornamelijk informatiesystemen maar ook bijvoorbeeld interne-controlesystemen, milieuzorgsystemen, kwaliteitssystemen e.d.). Hier wordt de context van informatie gevormd door de bedrijfsprocessen waaraan een economische entiteit haar bestaansrecht ontleent en de systemen. Voorts wordt in deze classificatie binnen het informatiedomein een nader onderscheid gemaakt naar de kwaliteitsaspecten relevantie en betrouwbaarheid. In tabel 1 is deze classificatie weergegeven met per cel een aantal voorbeelden die zijn ontleend aan de resultaten van het onderzoek van het Elliott Committee, de resultaten van de studie van Dassen e.a. (1999) naar de mogelijkheden van bepaalde, door het Elliott Committee beschreven assurance services in de Nederlandse markt, en dienstaanbiedingen door accountants blijkens brochures en krantenartikelen. In dit schema kan de traditionele jaarre-

Tabel 1: Een classificatie van assurance services

\begin{tabular}{|c|c|c|}
\hline Bedrijsprocessen & Informatie & Systemen \\
\hline - Strategiebeoordeling & Betrouwbaarheid & - Onderzoek naar de effectiviteit van de \\
\hline - Verbetering van bedrijfsprocessen & - Uitbesteding van de interne & administratieve organisatie \\
\hline - Beoordeling van de controlerisico's van & accountantscontrole & - Beoordeling van de beveiliging van \\
\hline dc eigen entiteit & - Beoordeling van informatie in & informatiesystemen \\
\hline - Beoordeling van de kwaliteit van de interne & een milıeujaarverslag & - Diensten in het kader van ICT- \\
\hline accountantsdienst & - Samenstellen van een milieujaarverslag & risicobeheersing \\
\hline - Ondernemingswaarderingen & - Beoordeling van schattingen betreffende & - Beoordeling van controlemaatregelen \\
\hline - Naleving milieuregels & uitstoot van stoffen die schadelijk (kunnen) & - Testen van modellen voor bedrijfs \\
\hline - Naleving privacywetten & zijn voor het milieu & voering \\
\hline - Waardering van aandelenportefeuilles & - Beoordeling van de redelijkheid van & - Beoordeling van ICT-beheersings- \\
\hline - Onderzoek naar mogelijkheden voor & een overnamebod & maatregelen \\
\hline belastingvoordelen en subsidies & - Actuariële berekening van & - Benchmarking met betrekking tot \\
\hline - Controle op de naleving van wet-en regelgeving & pensioenverplichtingen & ingaande en uitgaande logistiek \\
\hline - Onderzoek naar mogelijkheden tot het & Inbrengverklaring & - Beoordelen en testen calamiteitenplan \\
\hline vergroten van & - Subsidieverklaring & - Fraudepreventie \\
\hline de aandeelhouderswaarde & - Oplageverklaringen & - Beoordeling van het systeem van \\
\hline - Beoordeling van het frauderisico & - Due dilligence-onderzock & risicomanagement \\
\hline - Beoordeling van de interne verrekenprijzen & & - Beoordeling van het milieumanage \\
\hline - Advisering omtrent de herstructurering & Relevantie & mentsysteem \\
\hline van de onderneming & - Kostenanalyse & - Ontwikkeling van een systeem van \\
\hline - Begeleiding beursgang & - Beoordelen van de geschiktheid van & prestatiemeting \\
\hline - Investeringsbeoordeling & managementinformatie & - Certificatie van websites \\
\hline - Naleving mensenrechten & - Ontwikkeling balanced scorecard & - Audits van ESCROW van broncode \\
\hline - Verklaring bij de naleving van service & - Informatieverstrekking inzake prestaties van & - 'Chinese wall'-certificaat \\
\hline level agreements & afdelingen en functionarissen & - Kwaliteitstoets afhankelijkheids- en \\
\hline - Keurmerk effectenhandel & - Identificatie van kritieke succesfactoren & kwetsbaarheidsanalyse in het kader \\
\hline $\begin{array}{l}\text { - Nomenontwikkeling voor het beheer } \\
\text { van beleggingsfondsen }\end{array}$ & - Informatiebehoeftenbepaling & van de informatiebeveiliging \\
\hline
\end{tabular}


keningcontrole voornamelijk worden gepositioneerd in de kolom informatie/betrouwbaarheid. De andere vormen van assurance spelen voornamelijk een rol in de overige kolommen.

Om de risico's voor accountants als aanbieders van assurance services systematisch te inventariseren is het, gezien de sterke verwantschap tussen accountantscontrole en assurance (accountantscontrole is een vorm van assurance), efficiënt om aansluiting te zoeken bij bestaande onderzoeksresultaten op het terrein van de accountantscontrole. Een hoofdindeling van accountantscontroleonderzoek is die welke door Abdel-khalik en Solomon (1988, H1) wordt gehanteerd: (1) onderzoek met betrekking tot de markt voor accountantscontrole en (2) onderzoek met betrekking tot het proces van accountantscontrole. Het raamwerk van risico's voor accountants als aanbieders van assurance services dat op deze wijze ontstaat is weergegeven in tabel 2. Mede ten gevolge van de grote onderzoeksinspanningen die de laatste decennia op het terrein van de jaarrekeningcontrole (audit research) zijn verricht, is er een vrij goed inzicht in de risico's voor accountants op het terrein van de informatiebetrouwbaarheid. leonderzoek naar marktgericht en procesgericht onderzoek gevolgd.

\subsection{Markt}

Brackney en Helms (1996), Helms en Brackney (1998) en See en Mock (1999) hebben onderzocht op welke schaal assurance services momenteel worden aangeboden door accountantskantoren, alsmede op welke schaal deze in de toekomst zullen worden aangeboden. Hoewel de onderzoeken van elkaar verschillen in die zin dat de eerste twee betrekking hebben op de openbare accountantspraktijk in de Verenigde Staten en het laatste op de praktijk in Singapore, komen hun conclusies overeen: de meerderheid van de nu verstrekte assurance services ligt in het verlengde van werkzaamheden die worden uitgevoerd in het kader van de traditionele jaarrekeningcontrole. Het is echter de verwachting dat deze diensten in de toekomst ook zullen worden uitgebreid naar minder traditionele gebieden. De ondervraagde accountants waren van mening dat deze expansie vooral zal worden beïnvloed door de vraag naar deze diensten vanuit de markt.

Tabel 2: Raamwerk van risico's voor accountants als aanbieders van assurance services

\begin{tabular}{|l|l|l|l|l|}
\hline & Bedrifsprocessen & \multicolumn{2}{|l|}{ Informatie } & Systemen \\
\hline & & Betrouwbaarheid & Relevantie & \\
\hline Markt & & & & \\
\hline Proces & & & & \\
\hline
\end{tabular}

\section{Voorgaand assurance services- onderzoek}

Pas zeer recent is er een onderzoeksstroming op gang gekomen waarin de assurance services nader worden bestudeerd. Op basis van dit onderzoek kan al een eerste analyse worden gemakkt van de risico's die er zijn voor de accountant als hij zich gaat begeven op de terreinen van de assurance over bedrijfsprocessen, informatierelevantie, en systemen. Derhalve wordt in deze paragraaf een kort overzicht gegeven van onderzoek dat reeds heeft plaatsgevonden op dit terrein. Daarbij wordt de gebruikelijke hoofdindeling binnen het accountantscontro-
Fargher en Gramling (1996), Uzumeri en Tabor (1997), Hunton en Holstrum (1998), Fargher e.a. (1998), Havelka e.a. (1998) en Eilifsen e.a. (1999) richtten hun onderzoek op enkele verschijningsvormen van toekomstige attestation of assurance services die door openbare accountants zouden kunnen worden aangeboden. De door hen beschreven en onderzochte diensten hebben alle betrekking op gebieden die conform de hierboven genoemde onderzoeken van Brackney en Helms (1996), Helms en Brackney (1998) en See en Mock (1999) als minder traditioneel kunnen worden gekarakteriseerd. 


\subsection{Proces}

King en Schwart7. (1998) modelleerden hoe assurance service-aanbieders risico-inschattingen maken tijdens het plannen van hun werkzaamheden. Hun analytische resultaten geven aan dat accountants bij het plannen van de desbetreffende assurance service minder conservatisme betrachten dan bij de planning van een traditionele accountantscontrole. Evenals King en Schwartz (1998) richtten Srivastava en Mock (1998) hun onderzoek op de planning van assurance services. Zij ontwikkelden een zogenocm evidential reasoming-model met betrekking tot het verschaffen van een assurance service. Een dergelijk analytisch model geeft een gestructureerde aanpak weer ten behoeve van het verzamelen. evalueren en aggregeren van informatie die noodzakelijk is om een deugdelijke grondslag to bereiken.

Een aantal andere studies op het gebied van assurance services richt zich met name op de gevolgen van het verstrekken van assurance services voor de kemnis en vaardigheden van de accountant als verschaffer van deze diensten, alsmede de implicaties daarvan roor de opleiding van de accountant (zie Holstrum en Hunton. 1997: Vaassen c.a., 1999: Beets en Souther. 1999). De conclusies van deze studies duiden er onder meer op dat aceountants als verstrekkers van assurance services, meer dan vanuit hun traditionele controlewerkzaamheden, bekwaam moeten zijn op het terrein van de informatie- en communicatietechnologie. Bovendien moeten zij zich bij het beoordelen van het algehele functioneren van een organisatic niet slechts richten op de financiële aspecten van dit functioneren, mar in toenemende mate ook op zaken als de kwaliteit van de bedrijfsvocring of de efficiënte aanwending van productiemiddelen. Verder wordt geopperd dat accountants met behulp van standaarden voor assurance services (vergelijkbaar met Richtlijnen voor de Accountantscontrole) beter in staat zullen zijn om deze diensten te verstrekken.

Uit de studies zoals hier besproken kunnen de volgende risico's voor accountants als aanbieders van assurance services worden gedestilleerd:

de werkzaamheden breiden zich uit naar minder traditionele terreinen warop de accountant geen of onvoldoende ervaring heeft:

de vraag naar assurance services wordt overschat;

er worden minder conservatieve uitgangspunten gehanteerd bij de werkzaamheden in het kader van assurance services, waardoor de 'deugdelijke grondslag' daarvan kan worden aangetast;

de onathankelijkheid van de accountant komt in het geding door collisiegevaar;

de opleiding en deskundigheid van accountants schiet mogelijk tekort.

\section{Een inventarisatie van risico's voor accountants als aanbieders van assurance services}

In deze paragraaf wordt binnen het raamwerk van tabel $2 \mathrm{en}$ in aansluiting op hetgeen in de vorige paragraaf is vermeld over onderzock op dit terrein, een inventarisatie gemaakt van risico's voor accountants bij het aanbieden van assurance services.

\subsection{De martit roor assurance services}

Zoals reeds gesteld, is de term "assurance services" vanuit Noord-Amerika geïntroduceerd. Dit zou kunnen betekenen dat culturele en institutionele factoren wellicht de tocpasbaarheid en wenselijkheid van assurance services in de specificke Nederlandse situatic beinvloeden. Hicruit volgt het eerste risico:

Er zimn verschillen fussen Noord-Amerika en Europa op culturecel en institurioneel gebied natardoor assurance services in Europa wellicht minder commercieel perspectief vor accountants bieden dan in Noord-Amerika.

Er is nog onvoldoende inzicht in de onvang van de markt voor assurance services binnen elk van de cittegorieën bedrijfsprocessen. relevantic van informatie, betrouwbaarheid van informatie en systemen. Van belang is echter te allen tijde dat de assurance provider sericus wordt genomen door gebruikers van assurance services. Het gaat hier on de gepercipiecrde betrouwbaarheid van de assurance provider. Dit wordt relevanter naarmate meer afstand wordt genomen van het traditionele dienstenpakket van de accountant. Als het maatschappelijk verkeer de accountant 
niet als een volwaardig aanbieder van bepaalde vormen van assurance services beschouwt, dan heeft dit uiteraard vergaande consequenties voor de omvang van de vraag. Hieruit volgt het tweede risico:

Er is mogelijk géén behoefte an assurance services zoals aangehoden door accountants.

Er is onvoldoende inzicht in de terreinen waarop en voor welke specifieke assurance services de accountant uit hoofde van zijn competenties een concurrentievoordeel heeft ten opzichte van andere potentiële aanbieders van assurance services. Verder bestaat de mogelijkheid dat verschillen tussen accountantskantoren (reputatie, specialisaties, bestaande cliëntenkring en derge-

lijke) en tussen individuele accountants (persoonlijkheidskenmerken, ervaring, opleiding en dergelijke) van invloed zijn op het al dan niet succesvol opereren op de markt voor assurance services door accountants. Naast de verschillen tussen kantoren en verschillen tussen individuele accountants zal tevens de prijsstelling van invloed zijn op de mate van succes op de markt voor assurance services. Dit roept de vraag op in hoeverre kantoren bereid zullen zijn lage tarieven in rekening te brengen om assurance-opdrachten binnen te halen, en gekoppeld daaraan in hoeverre kantoren in het vervolgtraject bereid zullen zijn concessies aan de kwaliteit te doen om het initiële verlies op dergelijke opdrachten te minimaliseren. Hieruit volgt het derde risico:

Accountants zullen mogelijk een concurrentieslag ingaan met andere accountants en andere assurance service-aanbieders dan accoumtants on de gunst van de afnemer van deze diensten. De witkomst van deze concurrentieslag is onvoorspelhaar omdat de markt nog niet weet welke anhieder superieure assurance services anbiedt en welke prijzen daarbij behoren.

Hiermee samenhangend kan ook de vraag worden gesteld welke invloed het verstrekken van assurance services heeft op de kwaliteit van de traditionele accountantscontrole, en vice versa. Met dit laatste thema zijn we aanbeland bij een van de belangrijkste onderzocksvragen, namelijk: welke factoren beïnvloeden de kwaliteit van assurance services? Een hiervan afgeleide vraag betreft het spanningsveld tussen de vereiste en de aanwezige competenties bij accountants. Een wezenlijk element van competentie is het per- soonlijkheidsprofiel. Uit de vele variabelen die persoonlijkheid meten zijn hicr met name tolerantic voor ambiguïteit en risicomijdendheid van belang. Uit onderzoek blijkt dat accountants over het algemeen cen lage tolerantic voor ambiguïteit hebben en risicomijdend zijn (zic o.a. Vaassen, 1994). Hierdoor is er een mogelijkheid dat de accountant als assurance provider niet op de juiste wijze met het risico omgaat dat inherent is aan het aanbieden van assurance services waardoor deze aan relevantic zullen inboeten en hun eigen bestaansrecht ondergraven. Echter. anderzijds kan het in onvoldoende mate aanwezig zijn van de vereiste competenties en het koste wat kost willen concurreren op een nog onbekende markt ertoe leiden dat risico's in onvoldoende mate worden onderkend. Het verwachte risicomijdend gedrag blijft dan achterwege, waardoor een verhoogde kans op een claim ontstaat. De uitkomst van deze twee tegengestelde krachten is niet op voorhand te geven. Hieruit volgt het vierde risico:

Er kan zich een vergroting van het beroepsrisico voordoen, wat zich uit in een toenemend crantal chaims dat wordt uitgevardigd tegen accountants als anhieders van assurance services.

\subsection{Het proces i'm assurance-verschaffing}

De accountant in zijn traditionele rol zal weliswaar uitspraken doen over de kwaliteit van sommige aspecten van de bedrijfsvoering, maar er zijn altijd elementen van de bedrijfsvoering en aanverwante strategische gebieden waarmee de accountant zich in het verleden niet of slechts bij hoge uitzondering bemoeide. Met name de gedragsmatige aspecten van de management control en de kwaliteit van de strategische planning zijn voor de accountant over het algemeen onontgonnen terreinen. Accountants zijn geen psychologen en teren voor een groot deel op hun praktijkervaring waarin het omgaan met mensen dagelijkse kost is. Het kunnen inschatten en interpreteren van reacties van mensen op bijvoorbeeld prestaticbeloningssystemen, accountinginformatie, beslissingen van managers, geïmplementeerde milieuzorgsystemen of informatiesystemen vereist echter meer dan common sense-kennis van mensclijk gedrag. Ook de interacties met de operational auditor, de management consultant en andere concurrerende assurance providers behoren tot de categorie gedragsmatige aspecten waarop de accountant zich 
meer dan voorheen moet richten.

Een andere vraag die opkomt is die naar de betrouwbaarheid van de oordelen van accountants over de wijze van strategieformulering en -implementatic. De accountant heeft lange tijd weinig tot geen formele opleiding gehad in aspecten van strategische planning en management control. Het daardoor ontstane gebrek aan kennis en kunde kan mogelijk relatief snel worden gecompenseerd vanuit de praktijkervaring op het terrein van de controle en vanuit de uitgebreide mogelijkheden tot permanente educatie, maar er is nog onvoldoende inzicht in de mate waarin de accountant in staat zal zijn die additioneel benodigde kennis en kunde te verwerven. Aansluitend hierop kan de vraag worden gesteld naar de analogieën die bestaan tussen de risicoanalyse bij de accountantscontrole en dic bij assurance services. Een al te rigide vasthouden aan bestaande patronen van accountantscontrole kan de kwaliteit van de assurance services aantasten. Met de verbijzonderde aandacht voor systemen moet de accountant meer dan voorheen kennis en kunde hebben op het terrein van de ICT. Ook in dit aspect van assurance services bestaat nog onvoldoende inzicht. Hieruit volgt het vijfde risico:

Accountants beschikken mogelijk niet over de vereiste kennis en kunde om hepaalde typen assurance services te kunnen aunhieden.

De relevantie van informatie wordt door accountants weliswaar onderkend als een belangrijk kwaliteitsaspect van informatie, maar bij de uitvocring van de jaarrekeningcontrole wordt het primaat gelegd bij de betrouwbaarheid van informatic. De accountant kan evenwel cen rol van betekenis spelen bij het verbeteren van de relevantie van de interne en externe berichtgeving. Deze rol is echter nog onvoldoende uitgekristalliseerd en het is zeer de vraag of hierdoor niet de aandacht van de jaarrekeningcontrole wordt afgeleid waardoor deze aan kwaliteit zal inboeten. Hetzelfde geldt voor de assurance services gericht op de bedrijfsprocessen en de systemen van organisaties. Hieruit volgt het zesde risico:

Er ontstaat mogelijk een aantasting ran de kwaliteit van de jaarekeningcontrole doordat assurance services te veel energie en aandacht van de accountant opslokken.
Doordat accountants zich gaan begeven op onbekend terrein en er een grote kans is dat ze daarmee te grote risico's lopen, is het waarschijnlijk dat er op termijn een betere afbakening van taken en verantwoordelijklieden tot stand zal komen tussen accountants en andere specialisten. Dit speelt met name op het terrein van de ICT, waarop de ontwikkelingen razendsnel gaan. Een gebrek aan samenwerking tussen accountants en andere specialisten kan dan leiden tot suboptimale prestaties inzake assurance services. Hieruit volgt het zevende risico:

Er ontstaat mogelijk een aantasting van de kwaliteit van de dienstverlening ten gevolge van onvoldoende samenwerking tussen de accountant in de rol van assurance provider en andere specialisten.

De accountant is getraind in het uitspreken van een oordeel over de kwaliteit van systemen. Zo zal hij de effectiviteit van interne-controlesystemen beoordelen omdat hij dit nodig heeft bij de planning en uitvoering van zijn jaarrekeningcontrole en zal de ICT-auditor de opzet en werking van geautomatiseerde informatiesystemen toctsen en beoordelen. Het wordt echter anders als de accountant naar het maatschappelijk verkeer of naar specifieke opdrachtgevers ondubbelzinnige uitspraken gaat doen over de effectiviteit van de interne controle of over de integriteit van geautomatiseerde informatiesystemen bij een bepaalde onderneming. Het gaat hier duidelijk over assurance services. De accountant zal zorgvuldiger omgaan met deze beoordelingen omdat er een berocpsrisico ontstaat dat er voorheen niet was: hij kan nu worden aangesproken op een specifieke beoordeling die hij heeft gemaakt waar deze beoordeling in het kader van de jaarrekeningcontrole slechts een klein onderdeel van cen groter geheel was en als 'niet matericel' kon worden afgedaan. Risico's op dit terrein ontstaan met name doordat accountants zich in onvoldoende mate kunnen aanpassen aan de veranderde taakopvatting dic assurance services met zich meebrengen. Een belangrijk element hierin is de risicohouding van accountants. Uit onderzoek blijkt dat accountants over het algemeen een zeker risicomijdend gedrag vertonen. Hieruit volgt het achtste risico:

Accountants beschikken mogelijk niet over de vereiste risicohouding om assurance services te kunnen aanhieden: assurance services stellen 
hogere eisen aun het ondernemerschap van de accountant dan de jaarrekeningcontrole.

Ook het beladen thema van het collisiegevaar steckt bij assurance over systemen de kop op. Immers, de assurance provider zal mogelijk nieuwe systemen ontwerpen en implementeren waarna hij als controlerend accountant diezelfde systemen gaat beoordelen in het kader van de controle van de jaarrekening. Uit de tendens onder grote accountantskantoren om de consultancy-activiteiten af te stoten en de toenemende interne regulcring van aan de controle gerelateerde diensten is onder andere af te leiden dat het collisiegevaar een voortdurend punt van zorg is ${ }^{8}$. Hicruit volgt het negende risico:

Er ontstaat mogelijk een aantasting van de kwaliteit van de jaarrekeningcontrole door. collisie tussen de helangen van de accoumtant als assurance provider en de accountant als controleur van de jaarrekening.

\section{Samenvatting en conclusie}

Risico's die accountants lopen als zij assurance services gaan aanbieden, zijn factoren die ertoe kunnen leiden dat er fouten worden gemaakt bij het aanbieden van deze producten of dat er onvoldoende afstemming is tussen de vraag naar en het aanbod van deze producten. Deze problematiek kan bondig worden samengevat in de vraag of accountants de geprefereerde aanbieders zijn van assurance services. Het is opmerkelijk dat accountants al jaren bepaalde producten aanbieden die niet tot hun kerntaak behoren, maar waarnaar blijkbaar vraag is. Aidus is er reeds nu enig bewijsmateriaal voorhanden over de mogelijkheden en onmogelijkheden van bepaalde assurance services. Dit is echter voor beleidsmakers bij accountantskantoren niet voldoende om zonder meer nieuwe strategieën op te baseren. Om de invoering van assurance services als nicuw product van accountants enigszins beheerst te doen plaatsvinden, moet in de nabije toekomst meer inzicht worden verkregen in de risico"s voor accountants bij het aanbieden van deze diensten.

\section{Tabel 3: Samenvattend overzicht van de risico"s voor accountants als aanbieders van assurance services}

\begin{tabular}{|c|c|}
\hline \multicolumn{2}{|c|}{ De markt woor assurance serifices } \\
\hline RI & $\begin{array}{l}\text { Er zijn verschillen tussen Noord-Amerika en Europa op culturcel en institutioned gebied waardoor assurance services in } \\
\text { Europa wellicht minder commercieel perspectiel voor accountants bieden dan in Noord-Amerika. }\end{array}$ \\
\hline $\mathrm{R} 2$ & Er is mogelijk géén behoefte aan assurance services zoals aangeboden door accountants. \\
\hline R3 & 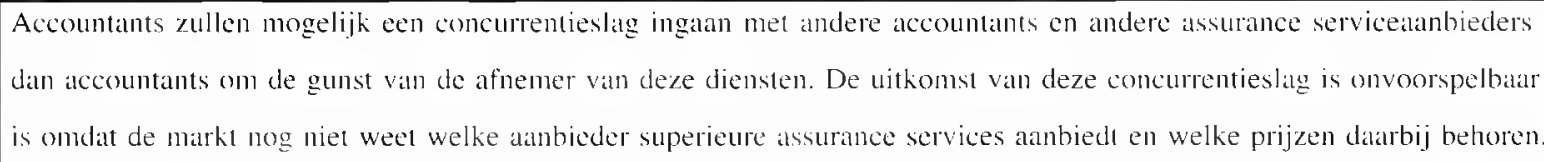 \\
\hline R4 & $\begin{array}{l}\text { Er kan zich een vergroting van het beroepsisico voordoen, wal zich uit in een toenemend aintal claims dat wordt } \\
\text { uitgevaardigd tegen accountants als aanbjeders van assurance services. }\end{array}$ \\
\hline R5 & $\begin{array}{l}\text { Accountants beschikken mogelijk niet over de vereiste kennis en kunde om bepalde typen assurance services te kunnen } \\
\text { aanbieden. }\end{array}$ \\
\hline R6 & $\begin{array}{l}\text { Er ontstal mogelijk een aantasting van de kwaliteit van de jalrekeningcontrole doordat assurance services te veel } \\
\text { energie en aandacht van de accountant opslokken. }\end{array}$ \\
\hline R7 & $\begin{array}{l}\text { Er ontstaat mogelijk een aantasting van de kwaliteit van de dienstverlening len gevolge van onvoldoende samenwerking } \\
\text { tussen de accountant in de rol van assurance provider en andere specialisten. }\end{array}$ \\
\hline R8 & $\begin{array}{l}\text { Accountants beschikken mogelijk niel over de vereiste risicohouding om assurance services te kunnen aanhicden: } \\
\text { assurance services stellen hogere eisen aan het ondernemerschap van de accountant dan de jaarrekeningcontrole. }\end{array}$ \\
\hline R9 & $\begin{array}{l}\text { Er ontstaat mogelijk een aantasting van de kwaliteit van de jaarekeningcontrole door collisie tussen de belangen van de } \\
\text { accountant als assurance provider en de accountant als controleur van de jatrekening. }\end{array}$ \\
\hline
\end{tabular}


In tabel 3 zijn de risico's voor accountants als aanbieders van assurance services samengevat.

Om de vele vragen over assurance services die er zijn te kunnen beantwoorden, is nader onderzock noodzakelijk. Dit onderzock zal ten dele kunnen aanhaken bij bestaand accountantscontroleonderzoek. Voor een groter deel zal het echter los moeten staan van wat in het verleden is gebeurd. Wellicht dat het de grootste uitdaging is voor onderzoekers om onderzoek te doen naar het bestaansrecht van assurance services zoals aangeboden door accountants en daarbij voldoende afstand te bewaren tot de traditionele accountantscontrole, het traditioncle onderwijs in de accountantsopleidingen. en bovenal de traditionele denkbeelden van de accountann.

\section{LITERATU UR}

Abdel-khalik, A.R. en I. Solomon (eds.), (1988), Research Opportunities in Auditing: The Second Decade, American Accounting Association, Sarasota, Florida.

American Institute of Certified Public Accountants, Special Committee on Assurance Services, (1997), Report of the Special Committee on Assurance Services. http://www.aicpa.org/assurance/ index.htm

Barkess, L. en R. Simnett, (1994), The provision of other services by auditors: Independence and pricing issues, Accounting and Business Research, no. 94

Beck, P.J., T.J. Frecka en I. Solomon, (1988), An empirical analysis of the relationship between MAS involvement and auditor tenure: Implications for auditor independence, Journal of Accounting Literature.

Beets, S.D en C.C. Souther, (1999), Corporate environmental reports: The need for standards and an environmental assurance service, Accounting Horizons, no. 2.

Brackney, K.S. en G.L. Helms, (1996), A survey of attestation practices. Auditing: A Journal of Practice and Theory, najaar.

Carcello, J.V., W. F. Messier Jr. en D.N. Ricchiute, (1998), Research Opportunities in Assurance Services, working paper

Dassen, R.J.M., (1998), Het Onzekere boven het Zekere? Onderzoeksvragen Rondom Assurance Services, oratie, Universiteit Maastricht.
Dassen, R.J.M., (1999), Onderzoeksvragen rondom de markt voor assurance services, Maandblad voor Accountancy en Bedrijfseconomie, juni.

Dassen, R.J.M., C.C.M. Schelleman, V.L.M.J. Cloudemans-Sweelssen, (1999), The Market for Assurance Services in the Netherlands, working paper, Universiteit Maastricht.

Eilifsen, A., W.R. Knechel, Ph. Wallage, (1999), External Assurance Services and Strategic Business Risk: An International Field Study, working paper, Universiteit van Amsterdam.

Elliott, R.K., (1994), Confronting the future: Choices for the attest function. Accounting Horizons, no. 3. September.

Elliott, R.K., (1995), The future of assurance services: Implications for academia, Accounting Horizons, December.

Elliott, R.K., (1997), Assurance service opportunities: Implications for academia, Accounting Horizons, December.

Elliott, R.K. (1998), Assurance services and the audit heritage Auditing: A Journal of Practice and Theory, supplement.

Fargher, N.L. en A.A. Gramling, (1996), A new market for attestation services: The performance presentation standards of the association for investment management and research, Auditing: A Journal of Practice and Theory, supplement.

Fargher, N.L., L.R. Gorman en M.S. Wilkins, (1998), Timely industry information as an assurance service: Evidence on the information content of the book-to-bill ratio, Auditing: A Journal of Practice and Theory, supplement.

Gray, G., R. Debreceny, (1998), Electronic Commerce Assurance Services and Accounting Information Systems: A Review of Research Opportunities, working paper, Nanyang Technological University.

Havelka, D., S.G. Sutton en V. Arnold, (1998), A methodology for developing measurement criteria for assurance services: An application in information systems assurance. Auditing: A Journal of Practice and Theory, supplement.

Helms, G.L. en K.S. Brackney, (1998), Attestation services: Opportunity for practice growth. The CPA Journal, February

Holstrum, G.L. en J.E. Hunton, (1997), New Forms of Assurance Services for New Forms of Information: The Global Challenge for Accounting Educators. paper gepresenteerd tijdens het achtste World Congress of Accounting Educators, Parijs, oktober.

Hunton, J.E. en G.L. Holstrum, (1998), The role of 
information systems auditors in WebTrust assurance. IS Audit \& Control Journal, no. 3.

International Federation of Accountants, (1998), International Standard on Assurance Engagements.

King, R.R. en R. Schwartz, (1998), Planning assurance services. Auditing: A Journal of Practice and Theory, supplement.

Pany, K. en P.M.J. Recker, (1984), Nonaudit services and auditor independence: A continuing problem, Auditing: A Journal of Practice and Theory, Spring

See, C. en T.J. Mock, (1999), The market for assurance services in singapore. Accounting and Business Review, July.

Shockley, R.A., (1982), Perceptions of auditor independence: A conceptual model. Journal of Accounting, Auditing and Finance, Winter.

Simunic, D.A., (1984), Auditing, consulting and auditor independence. Journal of Accounting Research, Fall.

Srivastava, R.P. en T.J. Mock, (1998), A Decision

\section{NOT E N}

1 De Engelse term 'assurance services' is reeds zodanig ingeburgerd in Nederland dat ten behoeve van dit artikel niet is gezocht naar een vertaling.

2 Zie bijvoorbeeld Waardenburg (1997), en Dassen (1998).

3 Onder andere de Task Force on Assurance Services van het Canadian Institute of Chartered Accountants (CICA), Special Committee on Assurance Services van het American Institute of Certified Public Accountants (AICPA), de Audit Section Task Force on Future Audit, Attestation, and Assurance Services van de American Accounting Association (AAA).

4 Zoals onder meer de AAA Annual Meeting in Dallas 1997, het International Symposium on Audit Research in Singapore 1997 en in Sydney 1998, en het Waterloo Assurance Services Research Symposium in Waterloo 1998
Theoretic Approach to WebTrust Assurance Services, paper gepresenteerd tijdens het International Symposium on Audit Research, Sydney, juni.

Uzumeri, M.V. en R.H. Tabor, (1997), Emerging management metastandards: Opportunities for expanded attest services, Accounting Horizons, March.

Vaassen, E.H.J., (1994), Auditors' Decision Processes in Audit Planning Stage Materiality Judgments, dissertatie, Universiteit Maastricht, Datawyse/ UPM, Maastricht.

Vaassen, E.H.J., G.L. Holstrum en C.C.M. Schelleman, (1999), Assurance Service Opportunities: The Effects of New Competency Requirements on Future Accounting Education, Practice and Research, PrimaVera Working Paper, Universiteit van Amsterdam.

Waardenburg, J., (1997), Control \& Audit in de Toekomst; Horen, Zien en.... : Van Accountant naar Assurance Provider, oratie, Vrije Universiteit, Amsterdam.

5 Dit kan uiteraard worden verklaard uit het feit dat de doorlooptijd van een onderzoek (van onderzoeksidee tot een officiële publicatie) veelal langer is dan drie jaar.

6 Een economische entiteit kan een onderneming zijn, maar ook een sector in de economie of bijvoorbeeld een consumptiehuishouding.

7 Dit onderscheid wordt minder relevant als wordt bedacht dat strikt genomen het geven van een kwaliteitskeurmerk ook een vorm is van additionele informatieverschaffing.

8 Er wordt gesteld dat een dergelijke combinatie de onafhankelijkheid van de accountants negatief zou kunnen beinvloeden en derhalve de kwaliteit van zijn/ haar dienstverlening zou kunnen doen verminderen (zie bijvoorbeeld Shockley, 1982; Pany en Reckers, 1984; Simunic, 1984; Beck e.a., 1988; Barkess en Simnett, 1994 